\title{
Dyslipidemia, diabetes and the heart. Present strategies, new therapeutic options, and a new hypothesis for the pathogeneis of atherosclerosis
}

\author{
Helmut Schatz MD
}

\begin{abstract}
Summary
To optimize cardiovascular outcome and long-term prognosis in diabetes mellitus is a key question of the present care. This review summarizes the present therapeutic strategies including cardiovascular risk analysis and individualized treatment goals as well as newer intervention options - enzyme antibodies, vaccination - partly already of the present, partly probably of the near future. A new hypothesis on the pathogenesis of atherosclerosis, instead of the hypercholesterolemia per se, the role of micro-infarcts in the vasa vasorum of the big arteries - including the coronaries - and their redeem factors are briefly adumbrated.

Key words: cardiovascular risk, risk score, therapeutic goals, future therapeutic options, new hypothesis on atherosclerosis

\section{Dyslipidaemia, diabetes és a sziv. A jelen kezelési stratégiái, új terápiás} lehetöségek, az atherosclerosis patogenezisének új hipotézise

Összefoglalás: A cukorbetegek keringési kockázatának lehetö legeröteljesebb mérséklése és a hosszú távú prognózis optimalizálása napjaink diabetesgondozásának kulcseleme. A közlemény áttekinti napjaink kezelési stratégiáit, beleértve a keringési kockázat felmérését és az egyénre szabott terápiás célok meghatározását, valamint az új - részben már a jelenben rendelkezésre álló, részben a jövöben, akár a közeljövöben alkalmazható - beavatkozási lehetöségeket lenzim antitestek gyógyszerként történö alkalmazása, „védöoltás"). Röviden érinti az atherosclerosis patogenezisének új hipotézisét is, elsödleges okaként az önmagában fennálló hypercholesterinaemiával szemben az artériák - köztük a coronariák - vasa vasorumaiban kialakuló mikroinfarktusok és kiváltó tényezöik szerepét hangsúlyozva.

- Kulcsszavak: keringési kockázat, kockázatbecslés, kezelési célok, új terápiás lehetöségek, atherosclerosis új hipotézise
\end{abstract}

Abbreviations

CKD: chronic kidney disease; CV: cardiovascular; CVD: cardiovascular disease; PCSK9: proprotein convertase subtilisin/cexin type 9; RNA: ribonucleinic acid; siRNA: small interfering RNA; T1DM, T2DM: type 1, type 2 diabetes; VLP: virus-like particles

$\mathrm{D}$ uring the European Congress of Cardiology in Rome, August 2016, the Joint Guidelines of this Association together with the European Atherosclerosis Society about the "Management of Dyslipidemias" has been published. ${ }^{1}$ In this review the relevant points for "Diabetes and Cardiovascular (CV) Risk" shall be discussed. 


\section{The present status}

First, "CV risk factors" have to be considered. A very high risk factor is, besides documented $\mathrm{CV}$

Table 1. Diabetes is a very high, or high CV risk factor

\begin{tabular}{|c|c|}
\hline Very high-risk & $\begin{array}{l}\text { - Documented CVD: previous AMI, ACS, } \\
\text { coronary and other arterial revasc., Stroke, } \\
\text { TIA, aortic aneurysm and PAD. Significant } \\
\text { plaque on coronary angiography or carotid } \\
\text { ultrasound. NOT some increase in intima- } \\
\text { media thickness of the carotid artery } \\
\text { - Diabetes mellitus (DM) with target organ } \\
\text { damage such as proteinuria, or with a } \\
\text { major risk factor such as smoking or } \\
\text { marked hypercholesterolaemia or marked } \\
\text { hypertension } \\
\text { - Severe Chronic Kidney Dis. (GFR }<30 \mathrm{ml} / \\
\text { min } / 1.73 \mathrm{~m}^{2} \text { ) } \\
\text { - SCORE }>10 \%\end{array}$ \\
\hline High-risk & $\begin{array}{l}\text { - Markedly elevated single risk factors, in } \\
\text { particular Cholesterol }>8 \mathrm{mmol} / \mathrm{L} \text { ( }>310 \mathrm{mg} / \\
\mathrm{dL} \text { ) (e.g. familiar hypercholesterolaemia) or BP } \\
\geq 180 / 110 \mathrm{mmHg} \\
\text { - Most other people with DM (except young } \\
\text { people with T1DM without major risk factors } \\
\text { may be at low or moderate risk) } \\
\text { - Moderate Chron. Kidney Disease (GFR 30-59 } \\
\mathrm{mL} / \mathrm{min} / 1.73 \mathrm{~m}^{2} \text { ) }\end{array}$ \\
\hline Moderate-risk & $\begin{array}{l}\text { - SCORE } \geq 1 \% \text { to }<5 \% \text {. Many middle aged } \\
\text { subjects in this category }\end{array}$ \\
\hline Low-risk & - SCORE < $1 \%$ \\
\hline
\end{tabular}

disease and severe chronic kidney disease (CKD), diabetes mellitus with target organ damage. At a high risk, besides cholesterol $>8 \mathrm{mmol} / \mathrm{L} />310$ $\mathrm{ng} / \mathrm{dL}$ or a blood pressure $\geq 180 / 110 \mathrm{mmHg}$, are most diabetic patients. Young type-1-diabetes patients without major risk factors, however, may be at low or moderate risk (Table 1).

Second, a CV risk score for the 10-year risk of fatal CV disease (CVD) has to be calculated for people in the different groups of countries. It depends on gender, smoking, age, total cholesterol and systolic blood pressure as well as on the country's epidemiologic data like CV mortality. E.g. Algeria, Belarus, Egypt, Russia and Ukraine belong to the countries with a very high risk, in contrast to low risk in many countries in western, northern or central parts of Europe (Table 2).

Risk factor screening has to be considered in men $>40$ ys and women $>50$ ys or postmenopausal. The risk score can assist in decisions, avoiding both under- and overtreatment. People at high or very high $\mathrm{CV}$ risk do not need risk scoring: They require immediate attention to all risk factors. These are patients with documented CVD, diabetes or chronic kidney disease (Table 3).

\section{Diagnosis}

LDL-cholesterol is the primary lipid analysis, total cholesterol is usually not enough for char-

Table 2. CV risk score for high and low risk countries (selection)

\begin{tabular}{|c|c|c|}
\hline Very high risk & High CV risk & Low CV risk \\
\hline $\begin{array}{c}\text { Algeria, Belarus, Bulgaria, Egypt, } \\
\text { Georgia, Latvia, Moldawa, Russia, } \\
\text { Tadjikisatan, Ukraine }\end{array}$ & $\begin{array}{c}\text { Croatia, Czech Republic, Estonia, } \\
\text { Hungary, Romania, Serbia, } \\
\text { Slovakia, Tunisia, Turkey }\end{array}$ & $\begin{array}{c}\text { Austria, Belgium, Cyprus, Denmark, Finland, France, Germany, } \\
\text { Greece, Israel, Italy, Luxembourg, The Netherlands, Norway, } \\
\text { Portugal, Slovenia, Switzerland, United Kingdom }\end{array}$ \\
\hline
\end{tabular}

Table 3. Treatment of dyslipidaemia in diabetes (T1DM and T2DM

\begin{tabular}{|c|c|c|}
\hline Recommendations & Class & Level \\
\hline $\begin{array}{l}\text { In T1DM and micro- albuminuria and/or renal disease, LDL-C lowering (at least } 50 \% \text { ) with statins as the first choice, } \\
\text { irrespective of the baseline LDL-C concentration }\end{array}$ & I & C \\
\hline $\begin{array}{l}\text { In T2DM with CVD or CKD, and without CVD }>40 y s \text { with one or more other CVD risk factors or markers of target } \\
\text { organ damage, the goal for LDL-C is }<1.8 \mathrm{mmol} / \mathrm{L}(<70 \mathrm{mg} / \mathrm{dL}) \text {, the secondary goal for non-HDL-C }<2.6 \mathrm{mmol} / \mathrm{L} \\
\qquad(<100 \mathrm{mg} / \mathrm{dL}) \text {, for apoB is }<80 \mathrm{mg} / \mathrm{dL} \text {. }\end{array}$ & I & B \\
\hline $\begin{array}{l}\text { In all T2DM with no additional risk factors and/or evidence of target organ damage, } \mathrm{LDL}-\mathrm{C}<2.6 \mathrm{mmol} / \mathrm{L}(<100 \mathrm{mg} / \\
\mathrm{dL}) \text { is the primary goal. Non-HDL-C }<3.4 \mathrm{mmol} / \mathrm{L}(<130 \mathrm{mg} / \mathrm{dL}) \text { and apoB }<100 \mathrm{mg} / \mathrm{dL} \text { are secondary goals. }\end{array}$ & 1 & B \\
\hline
\end{tabular}


Table 4. Lipid analyses

\begin{tabular}{|c|c|c|}
\hline Recommendations & Class & Level \\
\hline LDL-C is the primary lipid analysis & I & C \\
\hline CHDL-C: recommended to be analysed before treatment & I & C \\
\hline TG adds information about risk, indicated for diagnosis and choice of treatment & I & C \\
\hline Non-HDL-C is recommended to be calculated, especially in subjects with high TG & I & C \\
\hline When available, apoB should be an alternative to non-HDL-C & Ila & C \\
\hline $\begin{array}{l}\text { Lp(a) in selected cases at high-risk, for re-classification at borderline risk, and in subjects with a family history of } \\
\text { premature CVD }\end{array}$ & Ila & C \\
\hline $\begin{array}{l}\text { Total-C may be considered but is usually not enough for the characterization of dyslipidaemia before initiation of } \\
\text { treatment }\end{array}$ & Ilb & C \\
\hline
\end{tabular}

Table 5. Pharmacological treatment of hypercholesterolaemia

\begin{tabular}{|c|c|c|}
\hline Recommendations & Class & Level \\
\hline Prescribe statin up to the highest recommended, or highest tolerable dose to reach the goal & I & A \\
\hline Statin intolerance: Cholesterol resorption inhibitor (ezetimibe) or bile acid sequestrants, or these combined & Ila & C \\
\hline Goal not reached: statin combined with a cholesterol absorption inhibitor (ezetimibe: Ezetrol ${ }^{\oplus}$ ) & Ila & B \\
\hline Goal not reached: statin combined with a bile acid sequestrant (Colesevelam: Cholestagel, ${ }^{\odot}$ Welchol $^{\odot}$ ) & $\mathrm{llb}$ & C \\
\hline $\begin{array}{l}\text { ONLY in patients at very high-risk, with persistent high LDL-C despite treatment with maximal tolerated statin dose, } \\
\text { in combination with ezetimibe or in patients with statin intolerance, a PCSK9 inhibitor (ODYSSEY ESCAPE: } 63 \% \text { of } \\
\text { patients off apheresis) }\end{array}$ & Ilb & $\mathrm{C}$ \\
\hline
\end{tabular}

acterization of dyslipidemia before treatment. HDL-cholesterol may also be estimated before treatment. Triglycerides adds information about risk, indicates for diagnosis and choice of treatment. Lipoprotein(a) may be determined in selected cases at high risk (Table 4).

\section{Pharmacologic treatment of hypercholesterinemia}

Prescribe a statin up to the highest recommended or tolerable dose to reach the goal. Statin intolerance: etzetimibe or a bile acid sequestrant, or both goal not reached: statin combination with a cho- lesterol absorption inhibitor or a bile acid sequestrant. In selected cases: a PCSK9 inhibitor (Table 5).

Table 6. What else is new? Emphasis and recommendations for lifestyle

- No (stop) smoking

- 2.5-5 hours exercise per week

- Normal Body Mass Index (BMI): $20-25 \mathrm{~kg} / \mathrm{m}^{2}$

- Waist circumference max. $94 \mathrm{~cm}$ (men), $<80 \mathrm{~cm}$ (women)

- $\mathrm{RR}<140 / 90$

- $\mathrm{HbA}_{1 \mathrm{c}}<7 \%$

- Mediterranian diet, grain, vegetables, fruit, fish, olive oil, nuts (cf. PREDIMED study)

Table 7. Drug treatments of hypertriglyceridaemia

\begin{tabular}{|c|c|c|}
\hline Recommendations & Level \\
\hline Drug treatment should be considered in high-risk patients with TG $>2.3 \mathrm{mmol} / \mathrm{L}(200 \mathrm{mg} / \mathrm{dL}$ & B \\
\hline $\begin{array}{c}\text { Statin treatment may be considered as the first drug of choice for reducing CVD risk in high-risk individuals with } \\
\text { hypertriglyceridaemia }\end{array}$ & IIb \\
\hline In high-risk patients with TG $>2.3 \mathrm{mmol} / \mathrm{L}\left(\begin{array}{c}200 \mathrm{mg} / \mathrm{dL}) \text { despite statin treatment, fenofibrate may be considered in } \\
\text { combination with statins }\end{array}\right.$ & IIb \\
\hline
\end{tabular}




\section{Treatment goals}

In T1DM with renal involvement: LDL-lowering (at least 50\%) with statins irrespective mof the baseline LDL-concentration In T2DM with CVD or CKD or $>40$ years: $\mathrm{LDL}<1.8 \mathrm{mmol} / \mathrm{L} /<70$ $\mathrm{mg} / \mathrm{dL}$ In all patients with T2DM without additional risk factor $\mathrm{LDL}<2.6 \mathrm{mmol} / \mathrm{L} /<100$ $\mathrm{mg} / \mathrm{dL}$ (Table 6 and 7).

\section{New therapeutic options}

Besides the established two antibodies against PCSK9, evolocumab (Repatha ${ }^{\circledR}$ ) and alirocumab (Praluent $\left.{ }^{\circledR}\right)$, other technologies are in development for influencing PCSK9:2 siRNA Technology: Administration of small, interfering ribonucleotides, 20-25 base pairs long, results in non-active isoforms of PCSK9. This "gene silencing" technology has been tested in men in phase I and phase II has started.

\section{Vaccination}

A vaccine based on virus-like particles (VLP), against the binding domain of the PCSK9 for the LDL receptor is already tested in rodents.

\section{A new provocative hypothesis for atherosclerosis}

Not hypercholesterolemia but micro-infarctions of the small vasa vasorum in the arteries including the coronaries might be the cause of atherosclerosis especially myocardial infarction. ${ }^{3}$ Viral and bacterial infections, fine dust, and oxidized LDL cholesterol should lead to inflammation around the microinfarcted areas of the vasa vasorum being then transported from the adventitia inte the arterial lumen and deposited in the intima as plaques. $^{3}$

\section{Literature}

1. Catapano AL, Graham I, De Backer G, Wiklund O, Chapman MJ, Drexel H, et al.: 2016 ESC/EAS Guidelines for the Management of Dyslipidaemias. Eur Heart J 2016; 37(39): 2999-3058. doi:10.1093/eurheartj/ehw272

2. Schatz H: PCSK9-Hemmung statt durch Antikörper mit siRNA-Technologie oder durch Impfung. www.blog.endokrinologie.net, 19 0ctober 2016 (http://blog. endokrinologie.net/pcsk9-hemmung-sirna-technologie-impfung-2846/)

3. Haverich A: A surgeon's view on the pathogenesis of atherosclerosis. Circulation 2017; 135: 205-207. doi:10.1161/CIRCULATIONAHA.116.025407
Corresponding author:

Dr. Helmut Schatz

Buerkle-de-la-Camp-Place 1

D-44789 Bochum

E-mail: Helmut.schatz@rub.de 